\title{
TOWARDS A HISTORICAL SYNTHESIS OF THE CONCEPT OF IRONY
}

\author{
$M^{a}$ Angeles Ruiz Moneva. Universidad de Zaragoza
}

\begin{abstract}
The present essay aims to analyse the ways in which the concept of irony, characterised by its great versatility, has been approached throughout history, and how the different historical trends may have influenced the way it is understood nowadays, especially in the framework of relevance theory. Then it focuses upon the evolution of the recurrent traits of the relevance approach and relates it to other contemporary proposals. Finally, it refers to the latest trends in the investigation of irony and suggests possible lines of development or further research both within relevance theory and in other approaches.
\end{abstract}

\section{INTRODUCTION: A BRIEF SYNTHESIS OF THE HISTORICAL EVOLUTION OF THE CONCEPT OF IRONY UNTIL THE PRESENT CENTURY}

Even though the theory and practice of irony have not always gone hand in hand throughout history, and ours has been called "an ironical age", which must have been fostered by the growing scepticism and relativism, irony is probably as ancient as humankind. Despite the fact people may have a rough, intuitive notion of what the concept stands for, such a versatile notion has been historically open to a great variety of perspectives. What also seems to be the case is that many of the present concerns of contemporary mainstream tendencies on irony can be traced in some of the Classical authors, and have been a recurrent trait throughout the history of the concept. Among them, the following may be noted: the roles of the participants; the link of irony to the expression of a certain attitude; the importance of the context; whether the connection of irony with a certain tone is mandatory or not. Many of these topics will be dealt with in the present survey.

It is by going back to the Classics that the earliest manifestations of both the theoretical reflection and the practical usage of irony are to be found. Irony can often be traced in Greek comedies and tragedies, and it is in Ancient Greece that the links between irony and philosophy started, with the theoretical considerations made by Socrates, Plato and Aristotle. Most of the recurrent approaches to irony that can be found nowadays were already the concern of some, if not all, of these great authors. It has often been acknowledged that the views on irony held by Socrates and Plato are contained in the latter's most typical creation, the Dialogues, which with 
their perspectivism and interchange of ideas among which no particular standpoint is given preeminence offer a suitable context for the discussion and relativisation of every topic, as is to be expected from an ironic approach. If an aspect of perspectivism is the plurality of voices to be found in a text, this is both a feature and a problem of the dialogues held between Socrates and Plato, since they show a confrontation of different points of view, but it is not always easy to discern which of the views expressed in the Dialogues can be attributed to Plato himself, and which of them correspond to Socrates, as Kierkegaard noted already: "And thus we come now to the important problem in the Platonic philosophy, what belongs to Socrates and what belongs to Plato, a question we cannot dismiss, however painful it is to divorce them, closely united as they are" (1841: 31-32). In the Dialogues Socrates is on the whole a complex, multifaceted and ambivalent character, who may be defined as a wise fool, who can be understood only by those able to discern the irony of his words which give way to a deeper level of significance. Irony becomes a dialectic means necessary to unfold the quest for truth. The speaker, who is no other than Socrates himself, pretends to hold a proposition whose truth he fails to commit himself to, and which becomes a means to test his interlocutor's reaction. This is described in a dialogue between Socrates and Trasimaco, to be found in Plato's Republic: “... Here do we have Socrates' habitual irony! Well did I know that you would fail to give me an answer, and I had warned everybody that rather than answer, you would fall back on your usual sophistry". ${ }^{1}$ Some of the features characteristic of Socratic irony will be recurrent traits all through the history of the term. Among them, the following may be noted: the ironist as a pretender -though this is stated more accurately by Aristotle-; the contrast between appearance and reality; the dialogic nature of irony; the role and potential heterogeneity of the audience who may either grasp the irony intended or else fail to do so.

The role played by pretense in irony is retaken by Aristotle, who approaches irony from an essentially ethic point of view, in contrast to the almost exclusively intellectual or philosophical standpoint adopted by Socrates. However, in his Ethics to Nicomaco those characters who may have a role in an ironic interchange, defined as the eiron and the alazon, are characterised by an attitude of pretense, and not just the ironist or eiron alone, contrarily to what some twentieth theories have claimed. ${ }^{2}$

In his Poetics, Aristotle refers to the peripeteia as "the most powerful elements of emotional interest in tragedy" (1971: 52), which consists in a reversal or twist of situations, to be associated with the mistake made by the hero which brings about disaster, and which contains a high ironic load.

In Aristotle's Art of Rhetoric the relationship between irony and humour is also established, and the difference between them lies in that the ironist makes fun of himself, whereas the humorist tends to laugh at something or somebody external to himself. ${ }^{3}$

\footnotetext{
1 " $;. .$. aquí tenemos la habitual ironía de Sócrates! Bien sabía yo que no habías de responderme, y había prevenido a todos de que recurrirías a las argucias que sueles, antes que responder". (Plato 428-347 BC: 3839).

${ }^{2}$ Concretely these are Aristotle's words on the subject: "Therefore, with regard to truth, we shall name as truthfu theonewho remainsin themidde, and truthfunesstheintemedidedsposition, asfor pretense, on the one hand, that which is exaggerated, boastfulness and the one who holds it, boastful or alazon; on the other hand, that which is self-underestimated, dissimulatio, and the one who holds it, eiron" ( From Ética a Nicómaco, III, 18, 1419b, my translation). Hence, this shows that the theory of pretense (Clark and Gerrig, 1984) makes wrong predictions when it assumes that irony has been traditionally linked to an attittude of pretense on the part of the speaker. Moreover, even though Clark and Gerrig distinguish between two possible addressees, as many other theories do, on account of the fact that indeed some people may miss the ironic intention, while others may recognise it, the criterion in this case cannot be based upon pretense.

3 "Irony is more liberal than slapstick; for the one makes humour on one's account, but the slapsticker at the expense of the adversary" (1991: 260).
}

Odisea, $\mathrm{n}^{0} 1,2001$ 
The relationship between irony and humour is retaken by Cicero in his work De Oratore, where the distinction he makes between wit upon facts and wit upon words is important for the classical classification of irony into two different kinds: verbal and situational. Even though he refers to some of the sources of humour without explicitly associating them to irony, some of them are also at the ironist's disposal: the play upon words, the reversal of expectations, and the addressee's literal understanding of an expression which had been intended by the speaker in a different sense may be noted. If Aristotle had referred to irony as a tertium quid between two extremes, this idea is retaken by Cicero in his notion of decorum, which refers to the avoidance of extremes. On the whole, this was an important one in the classical rhetoric tradition. Another aspect that is retaken by Cicero is the relationship between irony and pretense, and it is him that comes to establish a close link between the two. Thus, the attitude of pretense may reflect that the speaker claims to be somebody or something other than she actually is, or she may pretend not to cope with something which she indeed understands.

About a century and a half later, Quintilian completed his treatise on rhetoric, which was to become the Classical reference work until at least the nineteenth century. A basic distinction is drawn between figures and tropes. Irony can be either, depending on the effect to be achieved. If irony is a trope, it indicates "... that class of allegory in which the meaning is the contrary to that suggested by the words" (Book VIII, 53-57, p. 333). For Quintilian, the pretense that may have been possibly meant by the addresser when speaking ironically is stronger in the case of a figure: "...the trope is franker in its meaning, and, despite the fact that it implies something other than it says, makes no pretence about it" (Book IX, p. 401). Thus, this definition of irony as a trope makes it clear that this author does not regard irony and pretense as mutually implicating each other. For him, irony is linked to pretense only if it is a figure, but not if it is a trope. The distinction between irony as being either a figure or a trope is made by Quintilian in the following terms: “... in the trope the conflict is purely verbal, while in the figure the meaning, and sometimes the whole aspect of our case, conflicts with the language and the tone of voice adopted" (Book IX, p. 401). This also shows how at least this author tends to consider certain cases in which the meaning of irony is not exclusively linked to the tone of voice. Strange though it may seem, too often the aspect of the tone has been regarded as a definitory trait of irony, even though it can obviously be appreciated only in oral communication, whereas in written communication it can only be perceived through the use of explicit indications. This shows that other factors, such as the context, should be considered. However rudimentary his approach to the context may be, Quintilian also signalled its importance when it comes to grasping the meaning of irony: "In the majority of tropes it is, however, important to bear in mind not merely what is said, but about whom it is said, since what is said may in another context be literally true" (Book VIII, 53-57, p. 333). This classification also allows Quintilian to establish a distinction between the possible intentions that the speaker may have in mind when using ironically, in a rather rudimentary form which has nevertheless lasted for long: irony may be used to express blame under a pretense of praise (as in You are so clever! or What a beautiful dress you are wearing!) and viceversa (as in You are so naughty!) (irony expressed either through blame by praise, or through praise by blame).

If the Classical Antiquity may be said to constitute the foundation for the Western rhetorical tradition, and to have constructed the basis for the contemporary on-going debate on irony, the study carried out by Dilwyn Knox (1989) shows that the Middle Ages offered but little contribution to the understanding of irony, when it was taken to be "a means of embellishing discourse" (1989: 7). The approach to rhetoric and to "figurative language" in general was too often made in very narrow terms and almost exclusively linked to its relationship to the expression of truth. Thus, ironia was often described as falsehood. 
A recurrent feature of the Middle Ages approach to texts was that different layers of interpretation were made, among which Aquinas noted the following in his Suma Theologiae: historical or literal, allegorical, moral and anagogical or related to eternal glory. Even though figures of speech were often condemned as they were associated to lying, Aquinas praises the use of figurative language in the Bible: "Hyperbole and figures of speech such as are found in Scripture are quite different" (1265: 419). In synthesis, the use of figurative language, and thus of irony, depended, as far as their adequacy and rightness are concerned, upon the purposes for which they were used. From a rhetoric point of view, in any case, the Medieval Ages did not bring any substantial improvement to the understanding of irony; rather, it tended to be accounted for in its narrowest sense of "meaning the contrary of what is expressed". For Dilwyn Knox the concept of contrarium must be traced to Aristotle's Categoriae, where he had defined four basic kinds of opposites: contraries, contradictories, correlatives and terms expressing either possession or privation. ${ }^{4}$ It appears that in some Medieval and Renaissance treatises the term contrarium was applied to all Aristotelian opposite terms, which must have resulted in the lack of differentiation between some of the possible shades of meaning conveyed by irony.

As in every field of knowledge, the Renaissance brought about a rediscovery of the Classics, and in the case of irony, scholars grew interested in ironia socratica. From this period until at least Romanticism, a gap is notoriously observed between the theorisation and the practice of irony: on the one hand, authors made an extensive use of irony, but the theoretical contribution was scanty, and the practice tended to follow the main principles stated by Socrates, Cicero or Quintilian. To mention just a few authors of the Anglo-Saxon culture, the writings of Swift, Dryden or Pope make extensive use of irony. However, there were very few theoretical contributions, and only two exceptions deserve consideration in the seventeenth and eighteenth centuries: Vossius and Mayáns. The work of Vossius (1606) is remarkable both for his attempts to break with some of the "myths" associated with irony, and because he draws attention to some issues which at present are still of central importance. Among those myths or false beliefs about irony, he denies any possible relationship between irony and lies: for him, the basic criterion to make a distinction between both lies in the speaker's intention. ${ }^{5}$ In an intuitive way, Vossius also notes the importance of the context when it comes to discerning irony. ${ }^{6}$

With regard to Mayáns, his definition of irony cannot be more classical, as he approaches it as meaning the contrary of what is stated. Nevertheless he rejects the condemnation of irony on moral grounds, and dissociates it from lying.

Therefore, it can be seen that the rhetoric debate on irony had been reaching similar conclusions during the seventeenth and eighteenth centuries, and practically no new approaches or proposals were being introduced. It was during the Romantic period that the

\footnotetext{
${ }^{4}$ The distinction to be made between these four terms is roughly as follows: contraries may either have an intermediate or not: good/ bad; tall/ short. Contradictory terms are opposed in the relationship affirmation/ negation, and therefore, if one of them is true, the other must necessarily be false: good/not good. Correlatives, such as double/ half, are explained by reference of one to the other. Finally, those expressing either possession or privation, such as sight/ blindness, refer to the same subject and are unidirectional

${ }^{5}$ These are Vossius' words where he refers to the importance of the speaker's intention to differentiate between irony and lies: "En effet, un discours n'est pas mesonger quand d'une part il n'y a aucune intentionde tromperie, et quand d'autre part ne sont trompés ni celui qui parle, ni celui à qui l'on parle" (1978 \{1606\}:504).

6 "Il faut être bien attentif aux CIRCONSTANCES et à tout pour éviter de supposer l'ironie là où elle n'est point, et de prendre, là où elle est, les mots en leur sens propre” (1606: 501).
}

Odisea, $n^{0} 1,2001$ 
concept of irony was revised at depth, and that the rhetoric approach was more or less openly questioned. The question of possible relationship between irony and humour, recurrent in the historical tradition, concerned the romantics, ${ }^{7}$ but on the whole a new standpoint was adopted. Even though Romanticism was a cultural movement that can be traced in many European countries, the main theoretical contributions of the movement are almost exclusively due to the German authors. In contrast to the proposals put forward until that moment, which had been purely rhetoric, a philosophical stance was mostly taken. Whereas reality and the possibility of art to reflect it (mimesis) had been almost taken for granted till that moment, then this tenet is openly questioned, and the creator sets himself aside, immersed in his own subjectivity, from where reality is perceived with paradoxical distance. In this conflicting relationship of the self with the world, irony plays a central role, for it helps the self to be liberated, which is nevertheless far from pleasant, as it may result in complete aloofness and detachment:

Here we therefore may perceive in the poet himself, notwithstanding his power to excite the most fervent emotions, a certain cool indifference, but still the indifference of a superior mind, which has run through the whole sphere of human existence and survived feeling. (August Wilhelm Schlegel, Lectures on Dramatic Art and Literature. Apud K. Wheeler, 1984: 215)

Therefore, irony ceases to be approached in rhetorical terms as meaning the opposite or something other than what is said. Irony may create a tension among all possible different meanings, whithout pointing at any of them, and on the whole any possible misunderstandings or ambiguities may be left unresolved.

This feature is further developed by Kierkegaard, who wrote at a time contemporary to some of the Romantics, and shared some of their central concerns. Thus, to give a representative instance, Hegel defines irony as "the infinite absolute negativity" (1835-42: 934), which he links to his system of dialectics, where the idea struggles for a synthesis of the infinite and the particular. Kierkegaard himself retakes the definition of irony given by Hegel, even though some of the traits of his approach also bring him close to a form of Existentialism. As such, one of his main concerns is the freedom with which the subject is endowed, and which can be either positive or negative. For Kierkegaard the subject is positively free if she speaks what she thinks, and if she can assume that her audience grasps the meaning she intends. Hence, irony would be a representative instance of negative freedom. As a result, as Kierkegaard himself notes, "in irony the subject is continually retreating ... in order to preserve itself in negative independence of everything" (1841: 257). The result will be the subject's tendency to the absolute detachment from everything, which is, if anything, painful.

The relationship between irony and humour, which was dealt with by classical authors such as Cicero, or some of the Romantics, was also a constant concern for some authors such as Meredith or Bergson in the transition between the nineteenth and the twentieth centuries. Thus, Meredith draws an interesting relationship between comedy, humour, satire and irony. For him, "irony is the humour of satire" (1877: 44) and it is characterised by its ambiguity. In contrast to satire, where the speaker tends to the detached fustigation of certain views, the ironist leaves his audience in doubt as to whether he is attacking them or not, which in turn implies that the audience must take a decision concerning the speaker's intentions, and therefore, the interpretation must be carried out in a certain context. Bergson insists on the exclusively human

${ }^{7}$ This was the case of authors such as Novalis or Richter. But once again the approach of the Romantics to this

Odisea, $n^{0} 1,2001$ 
nature of irony and humour, and on their interpersonal or social dimension, and even refers to the notion of echo, although he does not seem to confer it any special sense, whatsoever: "You would hardly appreciate the comic if you felt yourself isolated from others. Laughter appears to stand in need of an echo" (1900: 64).

In synthesis, the evolution which the concept of irony has undergone takes many different points of view, and shows that the ongoing debate has been much deeper than a rhetorical definition based upon the relationship between what is said and what is meant. Some of the main views which still concern critics nowadays, such as the links between irony and intention, or between irony and the context were approached by authors who devoted some thought to irony and whose works, as shown above, go back to the most ancient times.

Thus, we reach the present century, when the debate on irony offers new insights and is dealt with from a wide variety of different perspectives. In what follows, I will focus on the most outstanding theoretical contributions that have been put forward in this century, with a view to tracing the ways in which they have attempted to shed light on the understanding of such a proteic and complex resource and intellectual tool as irony.

\section{RECURRENT TRAITS IN PRESENT DAY THEORIES OF IRONY}

As in many other branches of knowledge, the theoretical thought on irony in the present century may be roughly characterised by the wide variety of different approaches that have been taken, from the most formalist to the most socially committed. With a view to attempting to reach some systematisation, we shall trace those traits which tend to recur in the different proposals, and see the connection which they may show with previous tendencies. It has to be noted that the present century has inherited from Romanticism the conflict between self and the world, and an ever-changing reality is seen with detachment and distance, in which irony has tended to play an important role.

For methodological reasons, a distinction is made between literary and linguistic theories in the analysis to be carried out next, and their recurrent traits and concerns will be synthesised below.

\section{2.a) - Literary approaches to irony}

As so many different proposals about the subject that concerns us have been put forward this century, I will not attempt to cover this material exhaustively, but rather to give a brief analysis of the most important and influential tendencies, with a view to underlining the recurrent traits that they may share with linguistic approaches.

Marxist criticism dealt with irony, especially in its initial stages. Thus, Lukács (1920) sees in irony a possible way to reconcile the dialectical opposition between the subjective and the objective, even though it has been claimed that in his later works he came to question the extent to which it can be said to reflect reality. ${ }^{8}$

With the New Critics, who proposed a method of the study of literature based on the close reading of texts, irony becomes a critical concept to analyse and criticise literature. This is the approach taken by Cleanth Brooks, in his articles "Irony and ironic poetry" (1948) and

\footnotetext{
${ }^{8}$ It was only at the sixties that Lukács' work started to be known in Western Europe, and Die Theorie des Romans has been generally assumed to belong to the earliest stages of his thought, when he still seemed to follow some of the tenets of idealism. Later on, Lukács will criticise every 'over-consideration' of form. (Ballart, 1994).
}

Odisea, $\mathrm{n}^{\circ} 1,2001$ 
"Irony as a principle of structure" (1949). In the latter, he refers to the context as the force which "... endows the particular word or image or statement with significance" (1949: 730).

The relationship between irony and satire is retaken by Northrop Frye, who claims that the difference between both lies in that whereas satire is socially committed, the ironist can remain aloof, and indifferent to social beliefs. This leads Frye to define satire as "militant irony" (1957: 223). However, one of the differences he establishes between both is controversial, for it clashes with most of the linguistic and pragmatic approaches, as he claims that irony exists regardless of an attitude: "Irony is consistent both with complete realism of content and with the suppression of attitude on the part of the author" (1957: 224, my italics). On the other hand, one of the basic traits of the most important pragmatic theories is precisely the link to be established between irony and the speaker's intention and attitude, as well as their inferential recognition by the audience or addressee.

Two of the most important contributors on irony in the present century, Booth and Muecke, have attempted to carry out a systematic, explanatory study of irony, which includes a description of the possible classifications of irony to be distinguished. As will be shown below, a feature they have in common with pragmatic approaches and with relevance is precisely the central role given to the expression of attitudes and intentions in their account of irony.

Nevertheless, one of the points which make Booth's analysis in particular very close to traditional theories is his maintenance of the classical distinction between literal and figurative language. He comes to distinguish four basic phases or steps in the production, recognition and understanding of figurative language in general: first, the rejection of the literal, surface meaning, due to some incongruity between the apparent meaning and the addressee's world knowledge; second, the search for alternative interpretations; third, taking a decision about the author's intentions; and fourth, the choice of definite interpretations "... with which we can rest secure" (1974: 12). Indeed, his classification of irony into stable and unstable seems to presuppose the existence of a hypothetical search for an alleged unique meaning to be found in a text. Precisely, Fish's rejection of the dichotomy between literal and figurative meaning questions the existence of such uniqueness of meaning. For him, the literal reading of a text is no less an interpretation than any figurative meaning, and this applies as well for the relationship between an ironical reading and its assumed literal counterpart:

... if irony is a way of reading, so is literalness; neither way is prior to the other, in the sense of being a mode of calculation rather than interpretation; both are interpretive ways, which are set in motion by cues and considerations that are themselves in place as a consequence of an interpretive act. (1989: 195)

As well as pragmatic approaches, contemporary literary theories on irony tend to emphasise the importance of these inferential processes. Thus, Booth himself stressses the importance of the context and the assumptions that the speaker may make about the resources she shares with the audience: “... it is impossible to say that only what is 'in the work' is relevant context, because at every point the author depends on inferences about what his reader will likely assume or know" (1974: 100).

Irony has also been thought over by some of the latest contemporary tendencies in literary criticism, which are otherwise different in their general tenets and objectives, such as Deconstruction, Reader Response Criticism or Post-Structuralism. Perhaps one of the most striking views on irony is De Man's, for whom irony is probably the best -if not the only- 
way available for the speaker to express her actually intentional meaning, despite -or precisely because of- its paradoxical character: "Curiously enough, it seems to be only in describing a mode of language which does not mean what it says that one can actually say what one means" (1971: 211). His orientation is openly influenced by the questioning of the possibility of meaning itself, a basic feature of Deconstruction.

The first studies of irony in the framework of Structuralism deal with oral irony (Cutler, 1974), and a distinction is drawn between spontaneous irony and provoked irony. Whereas every ironic utterance can belong to the category of provoked irony, spontaneous irony is characterised by specific syntactic and semantic features of the utterance. Cutler also draws a further distinction between the effects of irony, which may either be global and local. The effect is considered to be global if the negation of the whole proposition does not alter the expression of the intended irony, and cannot be paraphrased in a non-ironic form. On the other hand, the effect is local whenever the ironic meaning is not expressed through all the main clause, but what a part of the sentence, such as the attribute, presupposes in the context.

Another representative of the Structuralist tendency, though he will evolve throughout his work, is Jonathan Culler, for whom irony exists as long as it is perceived, and it has to be connected with the set of expectations that the addressee may have entertained: "The perception of irony thus depends upon a set of expectations which enable the reader to sense the incongruity or invraisemblance of literal or apparent meanings and to construct an alternative ironic meaning which accords with the vraisemblance which he has established for the text" (1974: 18). If expectations and their possible contradiction are basic features of irony for Culler, so is the context, which is associated to the common knowledge to be shared by addresser and addressee:

Given our knowledge of the world and our knowledge of the world of the novel, we are in a position to detect irony whenever the text appears to offer judgments with which we would not concur or whenever, with apparent disinterestedness, it does not pass judgment where we think a judgment would be appropriate. But, of course, we must have formed an impression of narrative vraisemblance ... (1975: 156)

If the reader's perception of irony is an important factor for Culler, the critical movement known as reader response criticism or Rezeptionästhetik is precisely based on the assumption that a given text is only completed when read or interpreted by a reader or addressee. For Jauss the reader tends both to identify herself with the hero and then to destruct this identification, so as to detach herself from it, and it is this tension that he terms as ironic identification.

More recently, Linda Hutcheon (1994) has also offered valuable contributions to the study of irony. She states that irony is particularly important to show how meaning is conditioned by the context, and how it is not made outside of particular situations. In the same way, irony is intentional, and consequently, lies upon an inferential act:

(Irony) would not be something intrinsic to a text, but rather something that results from the act of construing carried out by the interpreter who works within a context of interpretive assumptions. (...) Irony is always (whatever else it might be) a modality of perception -or better, of attribution- of both meaning and evaluative attitude. (1994: 122) 


\section{2.b) - Linguistic and pragmatic contemporary approaches to irony}

The beginnings of contemporary pragmatics are usually attributed to Grice, who in his 1957 paper "Meaning" distinguished between natural and non-natural meaning, and signalled the crucial role to be played by inference in the understanding of the latter: "(...) for $x$ to have meant NN anything, not merely must it have been 'uttered' with the intention of inducing a certain belief but also the utterer must have intended an 'audience' to recognize the intention of the utterance" (1957: 56). It is in this recognition of the speaker's intentions that inference plays an important role.

Nearly two decades afterwards, Grice referred to irony, which he described as a flouting of the first Maxim of Quality, "Do not say what you believe to be false" (1975: 53), and indicated that even though the addressee may first think that what is uttered by the speaker is entirely pointless, yet he assumes that she is aiming to be cooperative. ${ }^{9}$ Hence, the addressee concludes that the meaning that the speaker is trying to convey is some other than the literal sense, and is to be derived as an implicature, which is in any case related to the utterance: "... the most obviously related proposition is the contradictory of the one he purports to be putting forward" (1975: 53).

All in all, this analysis of irony does not depart significantly from traditional accounts, the only difference and contribution being Grice's introduction of the notion of implicature. This is one of the points made by Holdcroft, who, similarly to Sperber and Wilson, claims that Grice's theory gives no explanation of the reasons why the figurative meaning or indirect reading (IR) should be preferred to its literal counterpart or direct reading (DR).

The main guidelines of the Gricean analysis of irony will be followed by Leech (1983) and by Levinson (1983). If Grice had formulated the Cooperative Principle which governs communication, Leech seeks to complement it with a view to explaining why people choose being indirect, and to do so, he proposes some related pragmatic principles, mainly the Politeness Principle (PP) and the Irony Principle (IP). The Politeness Principle allows speakers "... to maintain the social equilibrium and the friendly relations which enable us to assume that our interlocutors are being cooperative in the first place" (1983: 82).

In Leech's model, the Irony Principle is established precisely upon the basis of a sort of balance between the two:

In being polite one is often faced with a CLASH between the CP and the PP so that one has to choose how far to "trade off" one against the other; but in being ironic, one EXPLOITS the PP in order to uphold, at a remoter level, the CP. (1983: 83, capitals as in the original )

In those cases, according to Leech, the Maxim of Quality is sacrificed. The Irony Principle is further defined by Leech as follows :

"If you must cause offence, at least do so in a way which doesn't overtly conflict with the PP, but allows the hearer to arrive at the offensive point of your remark indirectly, by way of implicature". (1983: 82, inverted commas as in the original )

What may be further questioned is whether this account of irony explained almost exclusively upon the basis of politeness is enough to deal with all possible cases of irony that may be found.

\footnotetext{
${ }^{9}$ Here, as elsewhere, unless indicated otherwise, the convention to refer to the speaker as "she" and to the addressee as "he" will be used.
} 
As for Levinson, he draws attention to the fact that meaning in language is not established through a process of codification and decodification, a point further developed by Sperber and Wilson in the distinction made between the code model and the inferential model of communication, being the latter the most important one. His approach to irony is basically Gricean, for it is described as a flouting of the Maxim of Quality.

Brown and Levinson, as well as other authors working in the framework of politeness theory, where irony is approached as a face-threatening act, have also pointed at inferences as necessary steps to recognise the speaker's intended meaning: "The clue to the correct interpretation of off-record FTAs lies in the making of some inferences which will allow the addressee to understand what was in fact intended by the speaker" (Alba Juez, 1994: 15).

Irony has also been approached from the standpoint of speech act theory. Thus, Haverkate (1990) has dealt with the way in which irony is manifested in the different kinds of speech acts, mainly assertives, directives, commissives and expressives. As occurs with Levinson or Leech, Haverkate's analysis of irony tends to view it as a violation of the Cooperative and the Politeness Principle, even though one of his main claims is that the speech act theory frame of reference is necessary to cover irony since the origin of irony is not to be found at the propositional level, but in the illocutionary force.

A recurrent trait in most of the pragmatic analyses of irony is its relationship with the expression of a certain attitude, and the inferences that have to be made in order to reach the meaning intended by the speaker. The connection between irony and feelings is noted by Grice as follows: " ... speaking ironically has to be, or at least appear to be, the expression of a certain sort of feeling or attitude" (1978: 125).

\section{THE CONTRIBUTION OF RELEVANCE THEORY: APPROACHES, DEBATES AND POSSIBLE FURTHER RESEARCH DEVELOPMENTS}

The study of irony has been one of the major topics dealt with by relevance theoreticians, for more than twenty years (1978-2000), being thus previous to the formulation of the theory itself, and merging in time with other proposals put forward above. In its evolution, it has rather tended to maintain certain aspects, it has also abandoned some others, but on the whole there are some areas which need further treatment, as shall be seen below.

The initial proposals on irony made by relevance theoreticians depart significantly from traditional approaches, and also share certain features with other pragmatic models. Thus, Sperber and Wilson's definition of irony starts with the rejection of one of the most widely held traditional theories on irony, that which claims that irony conveys the opposite meaning of what is said. Even though they make no allusion to other theories of irony, such as "meaning something different from", or expressing either "praise by blame" or "blame by praise", their rejection of traditional models of rhetoric goes further beyond these traditional notions of irony, since they come to reject the notion of figurative meaning altogether, a standpoint that is also taken by Fish (1989) more than two decades afterwards. ${ }^{10}$ It may be remembered here that Fish's standpoint has to do with the relativisation of what is a literal and a figurative version, since both of them are equally interpretations. In this case, Sperber and Wilson's main argument to reject the notion of figurative meaning is psychologically grounded, for it has to do

\footnotetext{
${ }^{10}$ Even though I shall refer to the 1981 Sperber and Wilson's paper, "Irony and the use-mention distinction", it may be remembered that this is an English version of a paper which appeared in the 1978 monographic issue of Poétique devoted to irony. The title of the French version was "Les ironies comme mentions" (Poétique 36: 399-412).
}

Odisea, $\mathrm{n}^{0} 1,2001$ 
with the fact that the potential choice between a figurative expression or its literal counterpart is left unexplained by traditional theories. ${ }^{11}$ This is also the reason why they also criticise other pragmatic approaches, mainly Grice's, due to the fact that the only thing he does in their opinion is to substitute the notion of implicature for the traditional dichotomy referred to above.

If there is a feature of pragmatic theories which is retaken by Sperber and Wilson is the link of irony with the expression of a certain attitude, usually of rejection and disapproval:

Furthermore, the crucial fact that ironical utterances convey not only propositions (which can be accounted for in terms of meaning and implicature), but also vaguer suggestions of images and attitudes, finds a natural description in the framework we propose. (1981: 296-7)

Indeed, it may be noted that the idea is not new, either, no matter how widely spread it may have become nowadays. Thus, a classical author such as Quintilian had already pointed at the importance of the attitude or the speaker's intentions to characterise irony.

The basic notions which will constitute the pillars of their theory of irony are also established now: use, mention and echo. The concepts of use and mention are defined as follows: "USE of an expression involves reference to what the expression refers to; MENTION involves reference to the expression itself" (1981: 303). As for the concept of echo, it is closely related to the above mentioned feature shared by most of contemporary pragmatic approaches: the connection of irony to a certain attitude. It is defined as follows: "....meant to indicate that the preceding utterance has been heard and understood, and to express the hearer's immediate reaction to it" (1981: 306).

The so called "mention theory of irony" has been criticised on the following grounds: as for the notion of echo, it has been sometimes perhaps understood too narrowly or literally. Thus, Robert Martin (1992) claims that no previous utterance needs to be involved for a speaker to be taken to speak ironically. Sperber and Wilson themselves have somehow shown a hesitant attitude regarding whether irony is necessarily echoic or not, and also concerning the kinds of echo to be distinguished.

Another question debated about this theory has been the notion of mention. First, Récanati has questioned openly that the same kind or concept of mention can be present in such different discourse phenomena as irony or indirect speech: "La mention qui intervient dans l'ironie n'es évidemment pas du même type que celle qu'illustre le discours rapporté (...)" (1981: 219; apud Perrin, 1996: 136). The consideration of irony as echoic mention has also brought about an altogether different standpoint from traditional approaches. This seems to lie at the core of an alternative analysis of irony, that of pretense (Clark and Gerrig, 1984). These authors claim to follow traditional theories of irony, where the speaker's attitude of pretense plays a central role in their opinion. However, the survey carried out here has shown that this is not an entirely homogeneous view: for Aristotle, both the eiron and the alazon, who may be associated to the

\footnotetext{
${ }^{11}$ With regard to this, Barbe also remarks correctly that even if this is indeed the case, it is also true that such psychological explanations were never within the scope of traditional theories: "Perhaps Sperber and Wilson are correct when they say that traditional definitions do not consider the whole psychological picture. However, that was not the purpose of these definitions. Traditional definitions were, indeed, established for the main purpose of educating an orator in the art of oratory. Thus in the area of linguistics, we still have much to add to the discussion of irony" (1995: 65).
} 
ironist and the victim, show an attitude of pretense. It was only with authors such as Cicero or Quintilian that the link between both became established, but the analysis shows on the whole a consistent lack of uniformity. This view of irony as pretense had also been held by Grice, although Sperber and Wilson overtly distance themselves from this view. If there is a tenet common to both pretense and mention approaches, as well as to more classical pragmatic approaches, is the appeal for the implicit in the expression of irony: thus, Clark and Gerrig retake Grice's view that if irony announces itself, this in turn "...would spoil the effect" (Griœ, 1978: 125, apud Clark and Gerrig, 1984: 122).

Another difference between mention and pretense approaches has to do with the role to be played by mutual knowledge. This was part of a wider debate, having to do with communication as a whole. For Clark and Carlson, communication in general presupposes that speakers "... share certain knowledge, beliefs and assumptions" (1982: 1). For these authors, mutual knowledge is based upon factors such as "physical co-presence, linguistic co-presence, and community membership" (1982: 6), and it is taken to be a necessary and sufficient condition for communication: "For the individual agents to bring off these acts jointly, they must share beliefs, and in a rather special way. They must have common or joint beliefs" (Clark and Carlson, 1982: 35). The pretense theory of irony relies explicitly upon the notion of common ground, or mutual knowledge: "A listener's understanding of an ironic utterance depends crucially on the common ground he or she believes is shared by the ironist and the audience -their mutual beliefs, mutual knowledge, and mutual suppositions" (Clark and Gerrig, 1984: 124, my italics). For Sperber and Wilson, on the other hand, mutual knowledge is neither a necessary nor a sufficient condition for communication, and is rather a consequence than a precondition for it. (Sperber and Wilson, 1982). But it seems that for the addressee to grasp the ironic meaning intended by the speaker, and thus rightly identify it, he may have to recognise certain allusions made by the interlocutor, without which the whole point may be missed. Katharina Barbe puts this in the following way: "In order to recognize an instance of irony, participants need linguistic, contextual, situational, and personal background knowledge" (1995: 16). However, the identification of any ironic allusion should be complemented with the recognition of the speaker's mocking attitude about it, and this is to be inferred by the addressee, and without it irony may also be equally missed.

For some authors, the gap between both theories is not so large as the forerunners of each have assumed to be. For Williams (1984), neither exhausts the phenomenon to be accounted for, and they are complementary rather than mutually exclusive. Authors such as KumonNakamura, Glucksberg and Brown have also proposed the substitution of a more general notion, that of allusion, for both mention and pretense: "... a necessary property of discourse irony is an allusion to some prediction, expectation, preference, or norm that has been violated" (1995: 5).

As for the distinction between echoic and non-echoic irony, in their earliest proposals, Sperber and Wilson (1981) already seemed to suggest that all irony was echoic, and rejected a possible dichotomy between echoic and standard irony, because this distinction was gradual, not discrete: for them, utterances can be more or less echoic. ${ }^{12}$ However, in their 1989 paper

\footnotetext{
${ }^{12}$ Concretely, they pointed out the following : "It might be suggested that there are two distinct types of irony: "echoic" irony, (...) whose interpretation involves a recognition of its status as mention, and "standard" irony, whose interpretation involves a recovery of its figurative meaning. The problem with this suggestion is that there is a whole range of intermediate cases between the clear cases of echoic irony and the "standard" cases ( ...). If there were two totally distinct processes, one based on mention and the other on figurative meaning, each resulting in a different type of irony, such intermediate cases should not exist" (1981: 309).
}

Odisea, $\mathrm{n}^{0} 1,2001$ 
on verbal irony, reprinted in Lingua in $1992{ }^{13}$, Sperber and Wilson claim that echoic utterances can express a great variety of attitudes, and also that the approach to ironic utterances in terms of echoic mention is too restrictive, "...because certain types of irony do not fit in the analysis of irony as echoic mention proposed in 1981" (1989:96). At this stage, they suggested the abandonment of the notion of mention, and the application of their concept of interpretive resemblance to irony. Some of the latest contributions on irony made by Sperber and Wilson (1998) have eventually made it manifest that irony is necessarily echoic. However, this seems to entail leaving some representative instances of irony unexplained, and so have admitted Sperber and Wilson: “... we have suggested that the echoic nature of verbal irony divides it from a range of non-echoic cases (situational irony, dramatic irony, romantic irony, irony of fate) which it resembles in some respects" (1998:290).

With regard to the kinds of echoes, their earliest proposals distinguish many different kinds, among which the following may be noted: depending on how close the reference of the echo is, the proposition being referred to may be the one just mentioned, a logical implication to be derived from it, it may be remote in either the context or in time, etc. It is significant that at this stage Sperber and Wilson admit the existence of anticipatory echoes, which will be nevertheless rejected later on.

Research on irony from the point of view of relevance has not been carried out only by Sperber and Wilson. Thus, Diane Blakemore (1992) follows the proposals made by the forerunners of the theory regarding the analysis of literary language, and of poetic effects in particular. In contrast to formalist approaches, in the framework of relevance theory, literary and poetic language are not seen as a estrangement from everyday speech. The difference between the two is seen in quantitative, but not qualitative terms. Hence, Blakemore draws a distinction between strong and weak communication, depending on the degree of the speaker's attachment or responsibility for the truth-conditions of the utterance, and of the addressee's freedom to reach his own conclusions. The relationship of irony to the attitude expressed by the speaker is also crucial for this author: "... in other cases the relevance of an echoic utterance lies in the information it gives about the speaker's attitude towards the attributed thought" (1992: 167).

\section{LATEST TENDENCIES IN THE ANALYSIS OF IRONY}

The end of the nineties has witnessed a renewed interest in irony, both from the point of view of relevance theory, as well as from other very different approaches.

\section{4.a) - Latest relevance proposals and debates on irony}

In the field of relevance theory, there have been deep criticisms as well as attempts to apply the model designed by Sperber and Wilson and followed by Blakemore to literature. Probably, as will be shown below, if there is a significant result of the latest debates on irony from a relevance perspective is that there is still much to be done in this field.

The controversies maintained about this approach affect substantial aspects, such as the question of whether irony is to be taken as necessarily echoic or not. For Ken-ichi-Seto,

\footnotetext{
13 These two papers are but one and the same. The 1989 version appeared in UCL Working Papers in Linguistics, 1 - 2. The 1992 version can be found in Lingua 87 (1992) 53-76. Here, any quotations will refer to the 1992 version, except for what is taken from the abstract, which appeared only in the earliest paper.
} 
and contrarily to Sperber and Wilson's rejection of irony being based on antinomy, both echo and semantic reversal can be mechanisms for the expression of irony. His approach is fairly eclectic, and thus he expands the analysis of echoic irony carried out by relevance theoreticians by pointing at certain devices by means of which echoic irony can be expressed. These can be lexical -such as the repetition of a certain word-, syntactic -such as the use of superlatives, exclamations and topicalization for emphasis-, stylistic -for instance, overtly emphatic politeness-, or prosodic -being intonation a case in point.

The approach to irony as a contrast between certain expectations and a different outcome is retaken by Hideki Hamamoto, for whom ironic utterances "remind us of the existence of a discrepancy between two cognitions" (1998: 265), and who advocates a cognitive approach to deal with this, even though no further solutions are proposed: "In order to capture this wide range, including some peripheral cases, we have to adopt a cognitive perspective which can account for a perceptual mechanism of irony on the cognitive level" (1998: 269).

The perspective adopted by Yamanashi criticises traditional analyses of irony for which it means the opposite of what has been said, since a speaker may speak what she believes to be the case about a certain situation and still be ironic. For this author, a shortcoming of the mention theory of irony is that it fails to specify the target of the speaker's criticism or negative attitude. The theory should account for those cases in which there is certain ambiguity as whether they are to be interpreted ironically or not, which in turn tend to blur the distinction drawn by Sperber and Wilson between use and mention. This means that in certain utterances the speaker may ambiguously admit the literal or propositional content of the utterance and yet be negative about what is being echoed by it: "These examples indicate that utterances cannot simply be distinguished between a case of mention and that of use. There are complicated cases where both functions are involved in one and the same utterance" (1998: 277).

Despite these remarks which criticise the present state of the art of the relevance proposals on irony, Sperber and Wilson still maintain, if only in a stronger way, that irony, at least verbal irony, is necessarily echoic: "...we would like to defend the view that verbal irony is necessarily echoic" (1998: 283). For them, what can be echoed has limits: on the one hand, there are universal beliefs, desires and norms which can always be echoed; on the other hand, expectations and desires which contradict these general assumptions and which can only be echoed if attributed to specific individuals. They also claim that by denying the approach to irony as semantic reversal borderline cases can be distinguished; that is, certain utterances can be more or less ironic. Their assumption of irony being necessarily echoic seems to hold only for verbal irony. As a result, they introduce a distinction between ostensive and non-ostensive forms of irony, which in their opinion "involve different cognitive mechanisms and should not be treated together" (1998: 291). Even though this has a clear parallel in their analysis of communication, where they also distinguish between ostensive and non-ostensive forms, the problem seems to be that in the case of irony this classification seems to overlap with the distinction between verbal irony, on the one hand, and other forms, which would include situational, dramatic, romantic, Socratic, etc. But the situation may turn a bit different in the case of those ironic communicative acts which are not ostensive, and which we shall associate with those instances which Sperber and Wilson have described as non-echoic (i.e., instances such as dramatic irony, situational irony, irony of fate, anticipatory irony, etc.). Here, there seems to be no intention involved, and therefore, it seems to have nothing to do with the inference of certain communicative intentions. And yet, we may assume that there is going to be an element of inference involved, if we can assume that communication is by nature an inferential process. The only thing is that perhaps, as those instances are also closely 
related to literature, the peculiarities of literary communication are to be taken into consideration, in the sense that it is delayed, and it unfolds at different levels, between different participants (for instance, characters appearing in a narrative, on the one hand; on the other hand, the communication which is established between the author and his audience or readership). A somehow tentative approach of explanation of some kinds of non-echoic varieties is given next, even though it possibly needs further development:

- in cases of anticipatory irony, the reader may make certain predictions, or, in any case, the unfolding of the different actions will refer back (allude or echo) what had been expressed before: the reader may go back to the hints or indices which had been foretold by the different characters, and then check the assumptions that had been entertained.

- in cases of dramatic irony, the reader, spectator or external addressee happens to know more than the characters involved. In relevance terms, we shall say that he enjoys a much wider cognitive environment than that of the characters or participants involved. The assumptions he may make will be confirmed as the action unfolds, thus enjoying a feeling of satisfaction.

- in cases of situational irony, or ironic situations, some expectations entertained by a character will be contradicted afterwards. Again, we propose to analyse these instances as cases of the degree of (in)accessibility to the context envisaged by other characters.

Some authors have also attempted to complete the relevance proposals on irony by applying certain tenets of the theory. This is the case of Yus Ramos (1997-98), who applies the relevance balance between efforts and effects as well as the role to be played by the context, and refers to the interpretation of irony as a balance between context accessibility and processing effort. His approach is therefore cognitive and relevance-oriented. His most remarkable contribution has three different aspects: first, the tracing of different contextual sources,${ }^{14}$ whose activation by the addressee is crucial for his understanding of irony, on condition that there are certain incompatibilities which may make him activate an ironic interpretation.

The second aspect has to do with the formulation of a criterion of optimal accessibility to irony, which springs as a consequence of the application of these contextual resources, and which goes as follows:

\section{CRITERION OF OPTIMAL ACCESSIBILITY TO IRONY}

The processing effort required for the interpretation of the intended ironic meaning of an utterance decreases in proportion to the increase in the number (and quality) of incompatibilities (detected by the addressee) between the information supplied by the inferential integration of simultaneously activated contextual sources (leading or leading plus supportive) and the information provided by the proposition expressed by the utterance. (2000a: 12)

\footnotetext{
${ }^{14}$ The contextual sources distinguished by Yus Ramos to which the addressee will attempt to have access to for the interpretation of ironic utterances are the following: encyclopaedic factual information; mutually manifest physical context or environment; the speaker's non-verbal behaviour; the addresssee's background knowledge of the addresser's biographic data; mutual knowledge; previous utterances of the conversation; and linguistic cues.
}

Odisea, $n^{0} 1,2001$ 
Finally, the fact that the faster or slower identification of irony depends upon the number of incompatibilities detected in the contextual sources available leads Yus Ramos to propose a terminological distinction between the bypassed 'proposition expressed' and the entertained 'proposition expressed'. This is introduced in relation to the question of the role which literal meaning is likely to play in the interpretation of ironic utterances. The proposition expressed may be either bypassed or entertained, depending on whether the speaker's intended interpretation remains implicit and inferrable from the context, or else the absence of adequate contextual information does not give way to possible implicatures, and the proposition expressed is processed as the speaker's intended interpretation. For Yus Ramos, three prototypical cases of irony comprehension may be predicted, depending on the level of manifest information, -provided in each of the three different cases by simultaneously activated contextual resources, both leading and supportive-, which can be high, low or insufficient:

- a) If the level of manifest information is high, then the mismatch between contextual information and the proposition expressed by the utterance will be identified fast, and so will the speaker's dissociative attitude be identified without much processing effort. For Yus, "this case typically leads to a bypassed 'proposition expressed" "(2000b: 13).

- b) If the level of manifest information is low, it will lead to a slow identification of the mismatch existing between contextual information and the proposition expressed by the utterance, which in turn "... does not foreground the speaker's dissociative attitude underlying the ironic interpretation of the utterance in a straightforward way" (2000b: 13). Here, two different possible situations may occur, depending on the addressee's reliance on contextual support: on the one hand, if he relies on this contextual support, weak though it may be, to reach the intended ironic interpretation, then the bypassed 'proposition expressed' is derived; otherwise, an entertained 'proposition expressed' will be derived.

- c) If the level of manifest information is insufficient, then the identification of a mismatch between contextual information and the proposition expressed by the utterance will not exist. As Yus Ramos notes, "this case typically leads to an entertained "proposition expressed", and "a misunderstanding of the utterance (intended implicature turned unintended explicature) will take place", where "the hearer is not aware of the ironic interpretation underlying the speaker's utterance" (2000b: 13).

\section{4.b) - Other recent approaches and proposals on irony}

The debate on irony from very different perspectives has reached our own time, and it has been the food for thought for very recent discussions. An interesting focus of debate, probably still unresolved, is the relationship of ironic utterances with the corresponding literal counterparts and their processing.

The classification of irony into different types is also far from homogeneous nowadays. If authors such as Muecke $(1970,1969)$ attemped to classify it on a literary basis, and tended to distinguish between verbal and situational irony, a classification which indeed goes back to the Classical Antiquity (Cicero), other authors have offered different possibilities. Thus, from a psycholinguistic and sociolinguistic perspective, Gibbs (2000) speaks of five different kinds: jocularity, sarcasm, hyperbole, rhetorical questions and understatements, and shows that there may be differences in the ways in which men and women use them.

Odisea, $\mathrm{n}^{0} 1,2001$ 
From a cognitive point of view, it is the interest of researchers to trace the relationship between the processing of ironic utterances and their literal counterparts, and whether the literal meaning of the utterance is processed at some moment (Schwoebel et al., 2000). It is also of interest to find out the roles to be played by the two brain hemispheres in metaphor and irony comprehension (Giora et al., 2000). Another field of study which requires further analysis is the way in which different individual and cultural backgrounds affect the production and perception of irony.

\section{CONCLUSIONS}

This paper has attempted to review some of the most remarkable and influential approaches to irony that have been proposed throughout history. It has proceded on the assumption that such a complex and proteic resource can be approached from very different perspectives, each of which can shed some light on concrete aspects of its production and understanding. It has also attempted to show that the research carried out thoroughout time has tended to observe recurrent traits and concerns, and indeed all the different authors and approaches traced may shed light on our understanding of the concept and the way it works, and we can be sure that much still remains to be said and written about a topic which is probably inherent to our own humanity: irony indeed makes us human.

\section{REFERENCES}

Alba Juez, L. 1994. "Irony and the other off-record strategies within politeness theory". Miscelánea, 15: 13 - 23.

Aristotle. 1931. (384-322 BC). "Etica a Nicómaco". Obras Completas. (Vol. VI). Madrid: Espasa-Calpe, Nueva Biblioteca Filosófica.

Aristotle. 1971. (ca. 330 BC). Poetics. In Critical Theory Since Plato. Ed. Hazard Adams. San Diego: Harcourt. 47-66.

Aristotle. 1991. (384-322 BC). The Art of Rhetoric. Harmondsworth : Penguin.

Aquinas, St. Thomas. 1989 (1265). Summa Theologiae. A Concise Translation. Ed. Timothy Mc. Dermott. London: Methuen.

Ballart, P. 1994. Eironeia. La Figuración Irónica en el Discurso Literario Moderno. Barcelona: Sirmio, Quaderns Crema.

Barbe, K. 1995. Irony in Context. Amsterdam/ Philadelphia: John Benjamins Publishing Co.

Bergson, H. 1956 (1900). “Laughter”. Comedy. Ed. W. Sypher. Baltimore and London: The John Hopkins University Press. 61-193.

Blakemore, D. 1992. Understanding Utterances. London: Blackwell.

Booth, W. 1961. The Rhetoric of Fiction. Chicago: The University of Chicago Press.

Booth, W. 1974. A Rhetoric of Irony. Chicago and London: The University of Chicago Press.

Brooks, C. 1962 (1949). "Irony as a principle of structure ". Literary Opinion in America. Vol. II. Ed. M. D. Zabel. New York: Harper Row. 729-741. 
Brown, P. and S. Levinson. 1978. Politeness. Cambridge: Cambridge University Press.

Cicero. 1952 (55-45 B.C). De Oratore. Ed. and trans. E.W. Sutton. London: Heinemann.

Clark, H. H. and T. Carlson. 1982a. "Speech acts and hearers' beliefs". Mutual Knowledge. Ed. N.V. Smith. London: Academic Press. 1-36.

Clark, H. H. and T. Carlson. 1982b. "Critics' beliefs about hearers' beliefs: A rejoinder to Johnson-Laird, Sperber and Wilks". Mutual Knowledge. Ed. N.V. Smith. London: Academic Press. 53-59.

Clark, H. H. and R. J. Gerrig. 1984. "On the pretense theory of irony". Journal of Experimental Psychology: General, 113: 121-126.

Culler, J. 1974. The Uses of Uncertainty. Ithaca and London: Cornell University Press.

Culler, J. 1992 (1975). Structuralist Poetics. Structuralism, Linguistics and the Study of Literature. London: Routledge.

Cutler, A. 1974. "On saying what you mean without meaning what you say". Papers from the 10th Regional Meeting of the Chicago Linguistic Society. Eds. M.W. La Galy, R.A. Fox and A. Bruck. 117-27.

Cutler, A. 1987. "The task of the speaker and the task of the hearer". Behavioural and Brain Sciences, 10: 715-16.

De Man, P. 1983 (1971). Blindness and Insight. Essays in the Rhetoric of Contemporary Criticism. Minneapolis: University of Minnesota Press.

Fish, S. 1989. Doing What Comes Naturally. Durham, NC: Duke University Press.

Frye, N. 1957. Anatomy of Criticism. Princeton: Princeton University Press.

Giora, R. 1997. "Understanding figurative and literal language: The graded saliency hypothesis". Cognitive Linguistics, 8: 183-206.

Giora, R. 1998. "When is relevance? On the role of salience in utterance interpretation". Revista Alicantina de Estudios Ingleses, 11: 85-94.

Giora, R. et al. 2000. "Differential effects of right- and left-hemisphere damage on understanding sarcasm and metaphor". Metaphor and Symbol,15: 63-83.

Grice, P. 1971 (1957). "Meaning”. Semantics. Eds. D.D. Steinberg and L.A. Jakobovits. Cambridge: Cambridge University Press. 53-59.

Grice, P. 1975. "Logic and conversation". Syntax and Semantics. Vol. III. Speech Acts. Eds. P. Cole and J. L. Morgan. New York : Academic Press. 41-58.

Grice, P. 1978. "Further notes on logic and conversation”. Syntax and Semantics. Vol. IX. Ed. P. Cole. New York: Academic Press. 113-127.

Hamamoto, H. 1998. "Irony from a cognitive perspective". Relevance Theory. Applications and Implications. Eds. R. Carston and S. Uchida. Amsterdam/ Philadelphia: John Benjamins Publishing Co. 257-270.

Haverkate, H. 1990. “A speech act analysis of irony”. Journal of Pragmatics, 14: 77-109.

Hegel, G.W.F. 1920 (1835-42). The Philosophy of Fine Art or Aesthetics. Trans. by F.P.B. Osmaston. London: G. Bell and Sons. 
Holdcroft, D. 1983. "Irony as a trope, and irony as discourse". Poetics Today, Vol 4, 3: 493-511.

Hutcheon, L. 1994. Irony's Edge: The Theory and Politics of Irony. London: Routledge.

Jauss, H. R 1986 (1977). Experiencia Estética y Hermenéutica Literaria. Ensayos en el Campo de la Experiencia Estética. Madrid: Taurus.

Kierkegaard, S. 1989 (1840). The Concept of Irony. With Constant Reference to Socrates. Ed. Howard V. Jong \& Edna H. Jong. Princeton: Princeton University Press.

Knox, D. 1989. Ironia. Medieval and Renaissance Ideas on Irony. Columbia Studies.

Kumon-Nakamura, S., S. Glucksberg and M. Brown. 1995. "How about another piece of pie: The allusional theory of discourse irony". Journal of Experimental Psychology: General, 124: 3-21.

Leech, G. 1983. Principles of Pragmatics. New York: Longman.

Levinson, S. C. 1983. Pragmatics. Cambridge: Cambridge University Press.

Lukács, G. 1971 (1920). Teoría de la Novela. Barcelona: Edhasa.

Martin, R. 1992. "Irony and universe of belief". Lingua, 87: 77-90.

Meredith, G. 1956 (1877). “An essay on comedy”. Comedy. Ed.W. Sypher. Baltimore and London: The John Hopkins University Press. 3-51.

Muecke, D. C. 1969. The Compass of Irony. London: Methuen.

Muecke, D. C. 1970. Irony. London: Methuen.

Perrin, L. 1996. L'ironie. Mise en Trope. Du Sens des Énoncés Hyperboliques et Ironiques. Paris: Éditions Kimé.

Plato. 1931 (428-347 B.C.). "La República o de lo justo". Obras Completas. Madrid: Nueva Biblioteca Filosófica.

Quintilian. 1921 (35-120). The Institutio Oratoria of Quintilian With an English Translation by E.H. Butler In Four Volumes. London: Heinemann and New York: G.P. Putnam's Sons.

Récanati, F. 1981. Les Énoncés Performatifs. Paris: Minuit.

Schwoebel, J. et al. 2000. "Obligatory processing of the literal meaning of ironic utterances: further evidence”. Metaphor and Symbol, 15: 47-61.

Seto, K. 1998. "On non-echoic irony". Relevance Theory. Applications and Implications. Eds. R. Carston and S. Uchida. Amsterdam/ Philadelphia: John Benjamins Publishing Co. 239-255.

Sperber, D. 1982. “Comments on Clark \& Carlson's paper”. Mutual Knowledge. Ed. N.V. Smith. London: Academic Press. 46-51.

Sperber, D. 1984. "Verbal irony: pretense or echoic mention?". Journal of Experimental Psychology: General, 113: 130-136.

Sperber, D. and D. Wilson. 1978. "Les ironies comme mentions". Poétique, 36: 399-412.

Sperber, D. and D. Wilson. 1981. "Irony and the use-mention distinction". Radical Pragmatics. Ed. P. Cole. New York: Academic Press. 295-318. 
Sperber, D. and D. Wilson. 1982. "Mutual knowledge and relevance in theories of comprehension". Mutual Knowledge. Ed. N.V. Smith. London: Academic Press. 6185.

Sperber, D. and D. Wilson, 1995 (1986). Relevance: Communication and Cognition. Oxford: Blackwell.

Sperber, D. and D. Wilson. 1998. "Irony and relevance: A reply to Seto, Hamamoto and Yamanashi". Relevance Theory. Applications and Implications. Eds. R. Carston and S. Uchida. Amsterdam/ Philadelphia: John Benjamins Publishing Co. 283-293.

Vossius, G.-J. 1978 (1643). "Rhétorique de l'ironie”. Poétique, 36: 495-508.

Wheeler, K. 1984. German Aesthetic and Literary Criticism. The Romantic Ironists and Goethe. Cambridge: Cambridge University Press.

Williams, J. 1984. "Does mention (or pretense) exhaust the concept of irony?". Journal of Experimental Psychology: General, 113: 127-29.

Wilson, D. 1994. "Relevance and understanding”. Language and Understanding. Eds. G. Brown et al. Oxford: Oxford University Press. 35-58.

Wilson, D. and D. Sperber. 1989. "On verbal irony”. UCL Working Papers in Linguistics, vol. 1: 96 - 117.

Wilson, D. and D. Sperber. 1992. “On verbal irony”. Lingua, 87: 53-76.

Yamanashi, M., 1998. "Some issues in the treatment of irony and related tropes". Relevance Theory. Applications and Implications. Eds. R. Carston and S. Uchida. Amsterdam/ Philadelphia: John Benjamins Publishing Co. 271-281.

Yus Ramos, F. 1997-98. "Irony: context accessibility and processing effort". Pragmalingüistica, 5-6: 391-410.

Yus Ramos, F. 1999. "Misunderstandings and explicit/ implicit communication". Pragmatics, 9 (4). Forthcoming.

Yus Ramos, F. 2000a. "On reaching the intended ironic interpretation". International Journal of Communication, 10. Forthcoming.

Yus Ramos, F. 2000b. "Literal/ non-literal and the processing of verbal irony". Pragmalingüistica, 8. Forthcoming. 